\title{
GLACIAL QUARRYING AND DEVELOPMENT OF OVERDEEPENINGS IN GLACIAL VALLEYS; MODELLING EXPERIMENTS AND CASE STUDIES AT ERDALEN, WESTERN NORWAY
}

\author{
Julien Seguinot
}

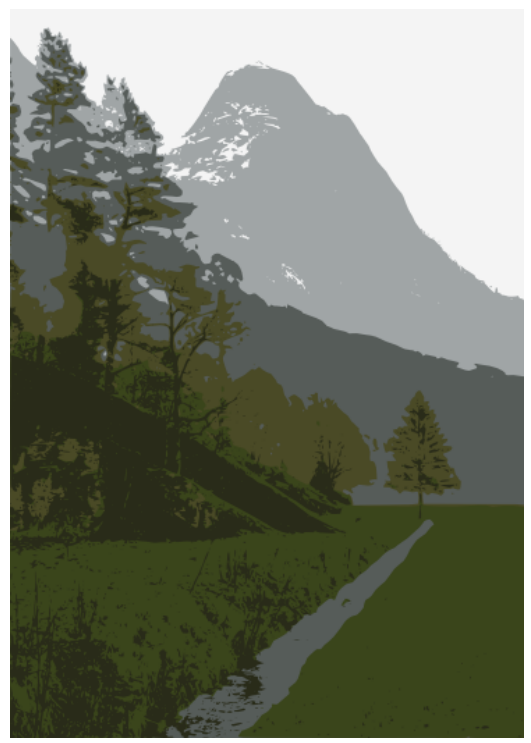

This work was done at Norges Geologiske Undersøkelse (Geological Survey of Norway) in Trondheim, between March and August 2008, under the supervision of Ola Fredin. It is within the scope of a five-month-long internship included in my first year of master studies at the Terre-atmosphèreocéan department of the École normale supérieure in Paris. 


\section{Contents}

1 Literature review

1.1 Glacial overdeepenings . . . . .

1.2 Large-scale erosion modelling . .

1.3 Process of plucking or quarrying

1.4 Plucking quantification . . . . . .

2 Field area description

2.1 Geographical setting . . . . . .

2.2 Geological setting . . . . . . . .

2.3 Quaternary geological setting . .

2.4 Morphology . . . . . . . . . .

3 Glacial plucking model

3.1 Ice flow model . . . . . . . . . 12

3.1.1 Continuity equation . . . 12

3.1.2 Navier-Stokes equation . . 13

3.1.3 Flow law . . . . . . . . 13

3.1.4 Sliding speed . . . . . . . 14

3.1.5 Non-dimensionalization . 14

3.2 Bed separation calculation . . . . 15

3.3 Fracture growth and erosion rate 16

3.4 Numerical implementation . . . . 17

4 Results

4.1 Observed erosional features . . . 18

4.1.1 Plucking and abrasion . . 18

4.1.2 Exploitation of the bedrock 18

4.2 Bedrock geology . . . . . . . . 18

4.3 Modelling results . . . . . . . . . 19

4.3.1 Unviable bed separation . 19

4.3.2 Pre-existing overdeepening 20

\section{Discussion}

5.1 The too high sliding velocity . . 20

5.2 Geomorphologic effects . . . . . . 21

5.3 Erdalen basins . . . . . . . . 22

\section{Abstract}

Erdalen valley in western Norway exhibit a set of several sediment-filled overdeepened basins carved in the rock by the Quaternary glaciers. This is a common phenomenon in presently or previously glaciated regions of the world. Despite of numerous glacial erosion theories, the origin of glacial overdeepenings remains confuse. The present study attempts to take a step further in the comprehension of the underlying processes. The results of a numerical model of glacial erosion, based on shallow ice flow modelling, bed separation and glacial plucking by sub-critical crack growth in conjunction with observations on Erdalen geology and geomorphology shows that small-scale overdeepenings are mainly the expression of bedrock resistance variations and flux pattern of the glacier. Glacial plucking, as modeled in this study, mainly contributes to headwall steepening.

\section{Résumé}

Arrachement glaciaire et développement d'ombilics dans les vallées glaciaires; modélisation et étude de cas à Erdalen en Norvège. La vallée Erdalen dans l'ouest de la Norvège occidentale présente une série de bassins remplis de sédiments et surcreusés dans la roche par les glaciers quaternaires. Les ombilics glaciaires se rencontrent communément dans 20 les régions qui sont ou furent couvertes par les glaces, et malgré les nombreuses théories d'érosion glaciaire, leur origine demeure mal expliquée. Cette étude a pour but de faire un pas dans la compréhension des processus sousjacents. Les résultats d'un modéle numérique d'érosion glaciaire fondé sur l'approximation de 
couche mince, le détachement du lit rocheux et l'arrachement par croissance de fracture sous-critiques sont associés à des observations géologiques et géomorphologiques effectuées à Erdalen pour montrer que les petits ombilics sont en général l'expression de variations dans la résistance de la roche mère et dans la forme du flux de glace. L'arrachement glaciaire tel qu'il a été modélisé dans cette étude explique en outre la formation d'arêtes.

\section{Introduction}

In past glaciated areas, ice has been a very efficient erosional agent during the Quaternary glaciations, overprinting the existing fluvial network. Glacially eroded valleys are often easily identified by their characteristic U-shaped transverse profile, but in most of the cases, they also show a very typical, stepped longitudinal profile, consisting of alternating bedrock thresholds and basins. These basins are called overdeepenings and are presently oftentimes filled with seawater, lakes or sediments.

The formation of glacial overdeepenings is not very well understood and there are many hypotheses explaining the processes involved (Sugden and John (1976, p. 182), Benn and Evans (1998, p. 348), MacGregor et al. (2000).) First, the basins could be due to of bedrock resistance variations (lithology, foliation, preexisting fractures.) Second, some overdeepenings are situated in the valley confluence points, which in turn suggest tributary glaciers could play an important role. Finally, overdeepenings could be formed by self-driven glacial processes leading to localisation of glacial erosion (Anderson et al., 2006), under the effect of climatic variations (Oerlemans, 1984), spatial distribution of subglacial water pressure, or water pressure temporal fluctuations (Hooke, 1991; Iverson, 1991).

Since the last deglaciation, many alpine landscapes became very unstable, because of the oftentimes very steep slopes exposures and weathering of rock by the glaciers (Terzaghi, 1962; Augustinus, 1995; Ballantyne, 2002), leading to the formation of numerous fluvial and rock avalanches deposits in the valley floors. Still today, and especially in Norway, the landscape remains strongly active and rockfall and rockfall induced tsunami hazards are serious (Blikra et al., 2006). Understanding glacial erosion processes and glacier bed morphologies could help unravel the localization of such events.

The aim of this study is to gain a better understanding of the formation of small scale overdeepenings, relying on previous works in this area, field observations in Erdalen (Sogn og Fjordane, Norway,) and a numerical processes-based glacial erosion model.

\section{Literature review}

\subsection{Glacial overdeepenings}

If few overdeepenings have been observed under present glaciers (Hooke, 1991), rather they have been exposed during the last deglaciation as flatbottomed valleys, glacial lakes, or fjords (fig. 1.) These basins have however been identified as evidence for glacial erosion for a long time, since rivers do not transport eroded material upslope, which indeed glaciers can do.

Numerous glacial overdeepenings can be qualitatively explain. They are very commonly delimited down-valley by a threshold of harder rock, as the glacier erodes deeper into the less resistant materials (Veyret, 1955; Beaudevin, 2008; Benn and Evans, 1998, p. 348). As we will see 

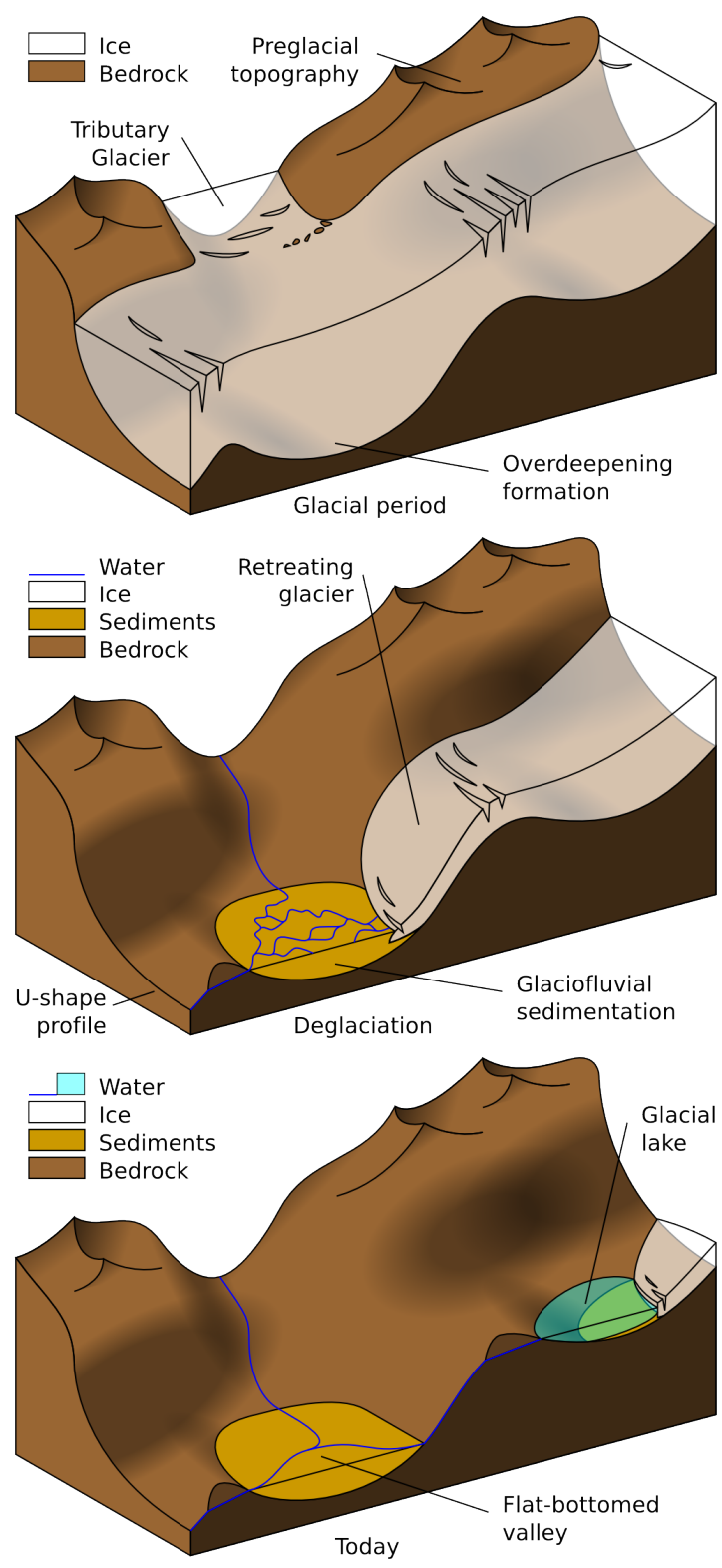

Figure 1: Sediment enfilling of glacial overdeepenings. After the glacier retreats, the basins are filled with water, glacial till, then glaciolacustrine, glaciofluvial and eventually fluvial deposits. later, preglacial joints density may play an even more important role in their formation (Matthes, 1930; King, 1959; Gordon, 1981). Finally, it is generally assumed that the local erosion rate of the bedrock is increasing with the ice discharge (Harbor et al., 1988; Anderson et al., 2006), and some superficial velocity measurements shows valley glaciers can locally accelerate just below, and sometime just above a confluence point (Gudmundsson, 1997; Wangensteen et al., 2006; NASA, 2008). This can explain why so many overdeepened basins are found at the junction point of one or several tributary glaciers (Veyret, 1955; King, 1959; MacGregor et al., 2000).

Aside from of all these different explanations, there are still some cases of stepped and overdeepened valleys, apparently carved in homogeneous bedrock, trough a regular channel of constant width. This is precisely the case of Erdalen, whose longitudinal profile exhibit several basins of depths around $50 \mathrm{~m}$ and lengths around $1 \mathrm{~km}$. Some authors discussed the importance of pre-existing fluvial morphology and meltwater erosion in their formation (Benn and Evans, 1998, p. 349), but this both points will not be brought up in the present study. Rather we will focus on glacial processes, which justify glacial erosion modelling.

\subsection{Large-scale erosion modelling}

A very simple glacial erosion model was proposed by Anderson et al. (2006). This model does not require any flow law for the ice, as the glacier movement is not described in term of velocity field and ice depth, but only ice discharge per unit width, which means integrated velocity over the entire ice depth. The equations are resolved in one dimension along the 


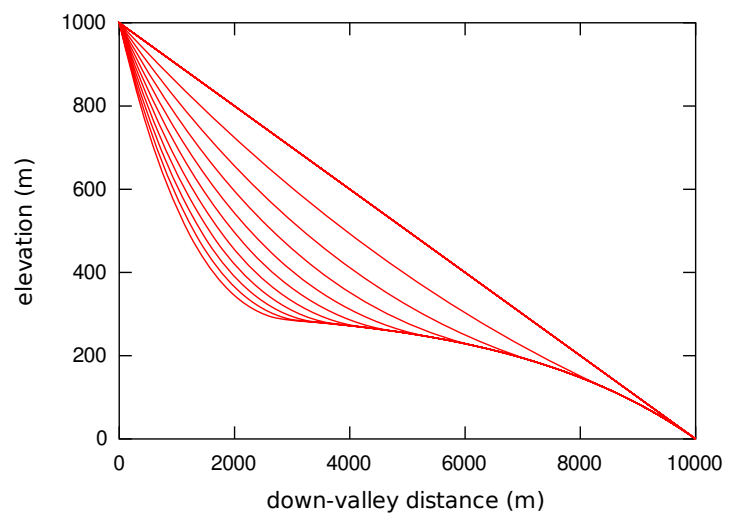

Figure 2: Simple model of glacial erosion of a linear valley profile. Valley floor elevation at 10 k.y. intervals. Glacial erosion progressively retreats up-valley while the glacier bed is flattened, but never overdeepened.

longitudinal profile and erosion is assumed to be proportional to the ice discharge per unit width. As a direct consequence of mass conservation, the ice discharge and, hence, glacial erosion are at maximum close to the equilibrium line, which marks the border between accumulation (snow fall greater than melting) and ablation (melting greater than snow fall) zones of the glacier. Anderson et al. (2006) argued that this glacial erosion maximum is responsible for carving overdeepenings, as the bottom of the valley is less eroded than the equilibrium line location. This is only true if the equilibrium line stay at the same position.

What Anderson and coworkers did not take into account in this paper is that as long as the ice erode the bedrock, the glacier is retreating as its bed is carved down to lower, and therefore warmer elevations. Under a steady climate, which can be modelled by a constant equilibrium line altitude (ELA,) the question is to know if the glacier erode faster than the equilibrium line retreats up-valley. A numerical implementation of Anderson et al. (2006) simplest model (uniform valley width, linear mass balance) shows that the valley floor is rather preferentially eroded up-slope than really overdeepened (fig. 2.) An overdeepening can only be obtained if the equilibrium line stay at the same position, and this means either that the valley floor is raising or the ELA is lowering.

Oerlemans (1984), which is a pioneer in longprofile glacial erosion modelling, used a slightly different model based on temperature-dependant ice flow and an empirical abrasion law, obtained the same results and concluded that overdeepenings are 'favoured by a gradually deteriorating climate, or slow uplift of the entire region.' The first hypothesis concerns but two phenomenons on very different time scales. The measured glacial erosion rates are usually at the order of magnitude of one millimeter per year (Burki et al., 2008), while the glaciers advances and retreats with a period of a few hundred years. A fifty-meters deep basin can not be carved by a slowly lowering glacier. Isostatic rebound following the deglaciation could explain a global uplift of the valley floor. But once more, this slow uplift will be overprinted by rapid climatic variations, and if isostasy could eventually play a role in the formation of very large overdeepenings (Kessler et al., 2008) or overdeepened cirques at the valleys upper ends (MacGregor et al., 2008), it can not explain the presence of repeated onekilometer long basins, like in Erdalen. This suggest that the understanding of the formation of overdeepened basins could lie in a better modelling of the erosional processes.

Harbor et al. (1988); Harbor (1995), demonstrated that the carving of the transverse Ushaped profile was very well simulated by a 
simple linear relationship between basal ice velocity and erosion rate. Later, Braun et al. (1999) incorporated this simple erosion law in a combined fluvial, hillslope and glacial twodimensional landscape evolution model, allowing coupling between tectonics and glacial erosion (Tomkin and Braun, 2002; Tomkin, 2003, 2008), which indeed had been done before with fluvial erosion (Kooi and Beaumont, 1994). The flow laws for the ice were based on the shallow ice approximation (SIA,) which will be detailed later in this study. MacGregor et al. (2000) noticed that the Yosemite $600 \mathrm{~m}$ deep overdeepening in California, USA was correlated with several hanging tributary valleys and tried to simulate this morphology using a one-dimensional model of the same kind as Braun et al. (1999), based on SIA and erosion proportional to ice velocity. The valley steps was well reproduced, but only a very shallow $10 \mathrm{~m}$ deep and $7 \mathrm{~km}$ long overdeepening resulted from the experiment, what can not be compared to the Erdalen features, or most other observed glacial overdeepenings.

Very recently, a lot of new work on glacial erosion modelling has been published, comprising improvements of numerical two-dimensional methods (Herman and Braun, 2008) and simulation of large-scale overdeepenings using simple erosion laws (Kessler et al., 2008; Tomkin, 2008). MacGregor et al. (2008) successfully modelled the formation of overdeepened glacial cirques using a empirical slope-dependant law for glacial quarrying, which definitely shows that the answer lies in the erosion rule, and therefore in glacial erosional processes understanding.

\subsection{Process of plucking or quarrying}

It is well known from field evidence that in a glacial valley, glacial erosion mainly consist

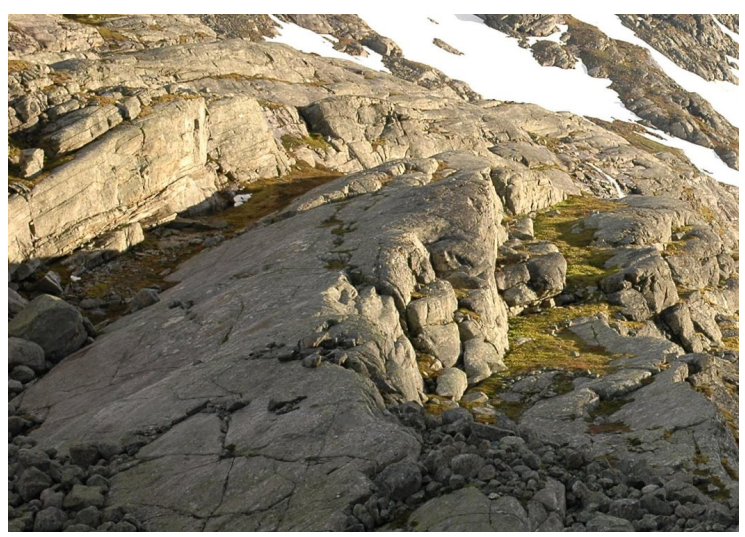

Figure 3: Erosional forms in Vesledalen, Western Norway. The plucking process takes advantage of the gneiss foliation (left-dipping on the picture) and existing fractures, and the top of the steps are slightly polished by abrasion.

of two processes called abrasion and plucking (or quarrying.) Abrasion involves polishing of the bed by ice-carried debris particles, and lead to the formation of striae and glacial polishes. Plucking (fig. 3) is the detachment of large fragments which diameter can reach up to several meters. In this study, we will assume plucking to be the main erosion agent, as abrasion needs much more energy to erode the same volume of rock. In addition, field observations from Hallet (2008) suggest abrasion to be very slow, and it is obvious that the formation of overdeepenings as well as glacial stepped profiles are dominated by plucking (Matthes, 1930; Hooke, 1991). Major plucking steps are often found on the slopes down-valley of the thresholds, while the up-valley dipping slope of the basins are usually more polished.

Although the process of plucking is still discussed, it is generally admitted that its mechanism is strongly linked to basal glacier hy- 


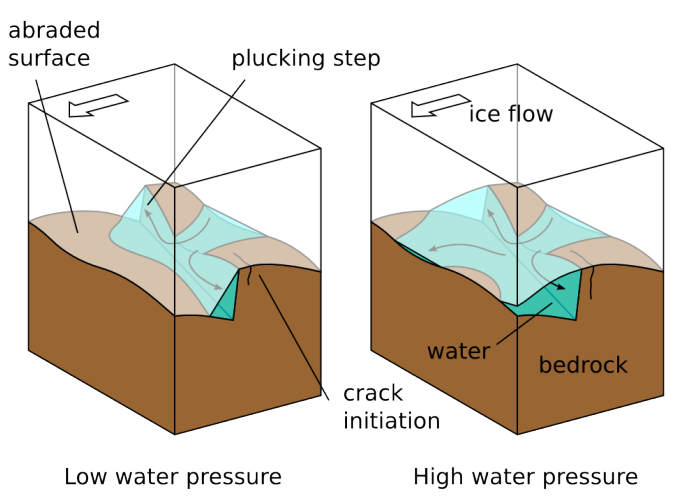

Figure 4: Linked-cavities drainage system. The size of the cavities depends on the water pressure. Erosion by plucking is more efficient under high water pressure. After Benn and Evans (1998, p. 109)

draulics. As glaciers are melting, supraglacial water infiltrates into the ice down to the bed to form a subglacial drainage system. This system can either take the shape of a channelized network, a thin water film, or a linked-cavities system (Benn and Evans, 1998, p. 109), which is the drainage form usually associated with glacial quarrying (fig. 4.) The water flows in a network of linked-cavities between the glacier and the bedrock at the pressure imposed by the glacier weight and its water contents. If this pressure is low, the cavities will tend to shrink, and the glacier weight will be distributed over a large bed surface, inhibiting erosion. Conversely, high water pressure will lead to large cavities and high effective pressure of the ice on the small outcrops still in contact with glacier bed, strongly favouring plucking. If water pressure however exceed a critical point, the glacier will tend to float over the water and slide down at high velocities. These steady-state effects were well re- produced by Hallet (1996) in a model we will discuss later. They are also responsible for seasonal variations in erosion rates and sliding velocities, as water pressure is higher during the melting season, due to infiltration of meltwaters from the surface into the glacier.

But subglacial cavities does not adapt instantaneously to short-term pressure fluctuations, as they are built by the moving glacier, and they are subjects to transient regimes. Iverson (1991) used a finite-elements ice flow model over a bedrock step to calculate effective pressure response of instantaneous water pressure fluctuations. An abrupt decrease in water pressure will cause the glacier to drop a bigger part of his weight on the rock and therefore increase the effective pressure, and the erosive power of the glacier. An experiment (Cohen et al., 2006) under Engabreen in Northern Norway confirmed these notions and showed that glacial plucking strongly depends on rapid water-pressure fluctuations.

Such daily water pressure fluctuations have been observed by Hooke (1991) under Storglaciären in Northern Sweden, above a small ridge separating two rock basins and causing the formation of crevasses at the glacier surface. The fluctuations were only observed at the summit and down-valley of the ridge, while the previous basin bottom of the ridge keep a constantly high water pressure during the measurements. This, and the fact that plucking marks are often observed down-valley of such rock bars, suggest that overdeepenings could be the result of a a positive feedback between erosion and morphology of the glacier. According to Hooke (1991), water would mostly infiltrate in the crevasse zones, which are naturally located over convex bed areas (fig. 5.) Water pressure fluctuation, due to daily cycles or weather changes, would 


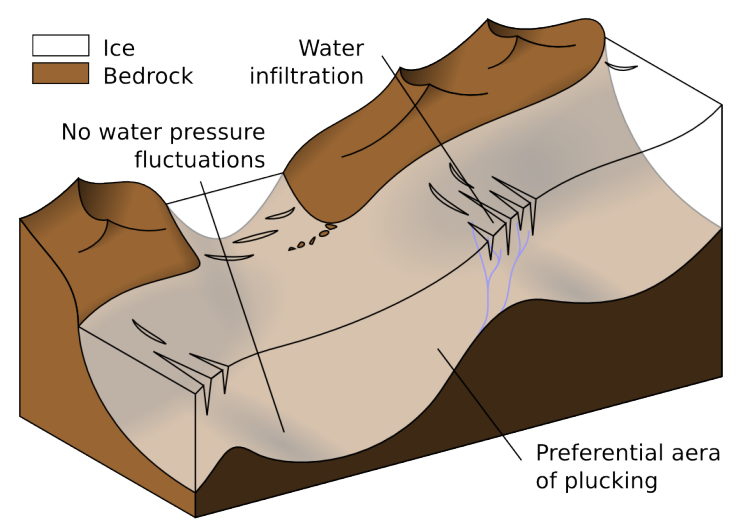

Figure 5: Conceptual model of overdeepenings formation involving erosional feedbacks between hydrology and morphology. After Hooke (1991).

propagate down to the glacier bed under this zones, favouring plucking on the down-valley side of the rock bars. The stepped bed relief would then be emphasized and new crevasses will appear over the thresholds.

This model needs however the water, or at least the pressure fluctuations, to propagate vertically into the glacier. This is viable in lower Storglaciären, which is only $150 \mathrm{~m}$ thick. Under a several hundreds meters thick glacier like the one we could expect to find in Erdalen during the last glaciation, crevasses only reach a negligible depth down into the total ice thickness. Below that, water conduits are not at the atmospheric pressure anymore and the glacier can be considered as a permeable porous medium. A parcel of water will then flow perpendicular to the Shreve's equipotential surfaces (Hooke, 2005, p. 201) and reach the glacier bed a significant distance down-valley of the initial crevasse. In addition, a pressure perturbation from the surface would be diffused through the glacier thickness and reach the bed on the both sides of the

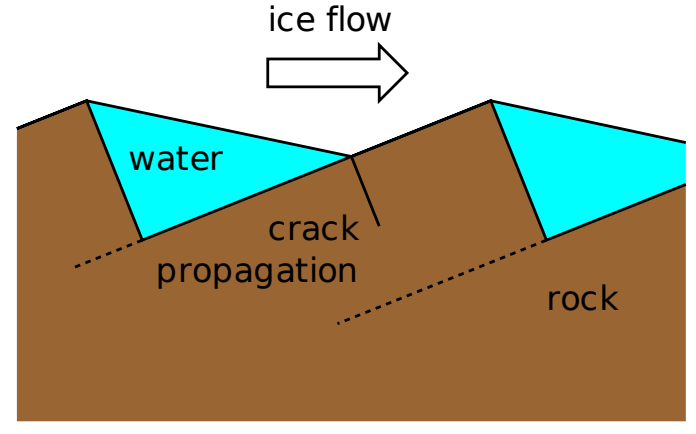

Figure 6: Idealised periodic bed for glacial plucking modelling. After Hallet (1996).

ridge, flattening the ridge rather than creating a positive feedback. The Hooke (1991) model can therefore not be applied in Erdalen where we envision a significantly thicker ice.

\subsection{Plucking quantification}

Hallet (1996) proposed a theoretical model of glacial quarrying, assuming the process is limited by sub-critical crack growth rate. This model uses an ideal periodic stepped bed profile (fig. 6) to calculate the size of subglacial cavities, then the ice-induced stress over the bedrock and crack growth velocity. The equations requires knowledge of several basal condition parameters, and are therefore difficult to be used in a landscape development model, as also admitted by 6 .

In all, it is evident to me that a new model of glacial erosion, based on realistic processes modelling nevertheless simple enough to be easily implemented in a numerical one-dimension longitudinal profile evolution model, is necessary. Results from the modelling work will then be compared to the observed overdeepenings and glacial erosional features in Erdalen. 


\section{Field area description}

\subsection{Geographical setting}

Erdalen is a glacial valley located in the municipality of Stryn, Sogn og Fjordane in Norway (fig. 7.) The valley starts at $29 \mathrm{~m}$ above sea level at the shores of Strynvatnet, a $20 \mathrm{~km}$ long lake which used to be part of the Nordfjord fjord system before isostatic rebound lifted it to its present position at $29 \mathrm{~m}$ above sea level. Erdalen waters mainly come from the melting of Erdalsbreen and Vesledalsbreen, two outlets glaciers of Jostedalsbreen, continental Europe's largest ice cap, whose highest point is the Lodalskåpa at $2083 \mathrm{~m}$ elevation. Like the rest of the western fjords region, the valley is also subject to a high precipitation rate. The tree limit is approximately at $700 \mathrm{~m}$ above sea level and the glaciers goes down to $900 \mathrm{~m}$.

\subsection{Geological setting}

The geology of Norway has been widely influenced by the Caledonian orogeny (500 - $390 \mathrm{Myr}$ BP.) Erdalen is however situated in an area of older rock, called the Western gneiss province. As indicated by its name, this precambrian basement mainly consist of orthogneiss, described as "granitic orthogneiss with bands or foliation, sometime migmatitic, gneiss with dioritic to granitic composition, sometime augen gneiss," in the map from Lutro and Tveten (1996).

The Jostedalsbreen area is hosting a large intrusion of quartz-monzonit (1031 kyr) to granitic rocks (1009 kyr.) Subsequently, they all have been strongly folded and deformed, especially during the Caledonian orogeny. According to the same map (fig. 8,) Erdalen bedrock mainly consist of orthogneiss, and quartz-monzonit can be found in the middle part of the valley. How- ever, as explained by one of the authors of the 1:250 000 map (Lutro and Tveten, 1996), this contact was not the object of a detailed mapping and should not be taken as an evidence for such small features as the Erdalen basins. To my knowledge, no more precise geological map of Erdalen area has been published yet.

In addition, according to Ole Lutro, whereas the Western gneiss province is associated with high topographies and deep glacial valleys, the different types of precambrian rocks does not shows any correlations with topography, which in turn suggest that the ensemble could be considered as an homogeneous block. However, the modelling results form Hallet (1996) showed that glacial erosion could be extremely sensitive to bedrock resistance variations, as a marble is eroded 1000 times faster than a granite. Even if such variations probably do not exist in Erdalen, second-order features like small-scale overdeepenings still have to be proved to not depend on second-order bedrock resistance variations. This is why field investigations are needed.

\subsection{Quaternary geological setting}

The Quaternary era is characterized by a succession of several glacial and interglacial periods. During the glacial periods, the climate is cooler and the ice cover large areas of Earth's surface, particularly in the northern hemisphere where several new ice sheets are formed. During the early Quaternary (3 Myr BP - 0.7 Myr $\mathrm{BP})$, small to medium scale glaciations emanating from the Scandes mountain range dominated in Scandinavia. During the last 700 kyr full scale ice ages have been the dominant mode of glaciation (Fredin, 2002). During these large glaciations, the Scandinavian ice sheets joined together with the Kara Sea ice sheets in northern Russia 


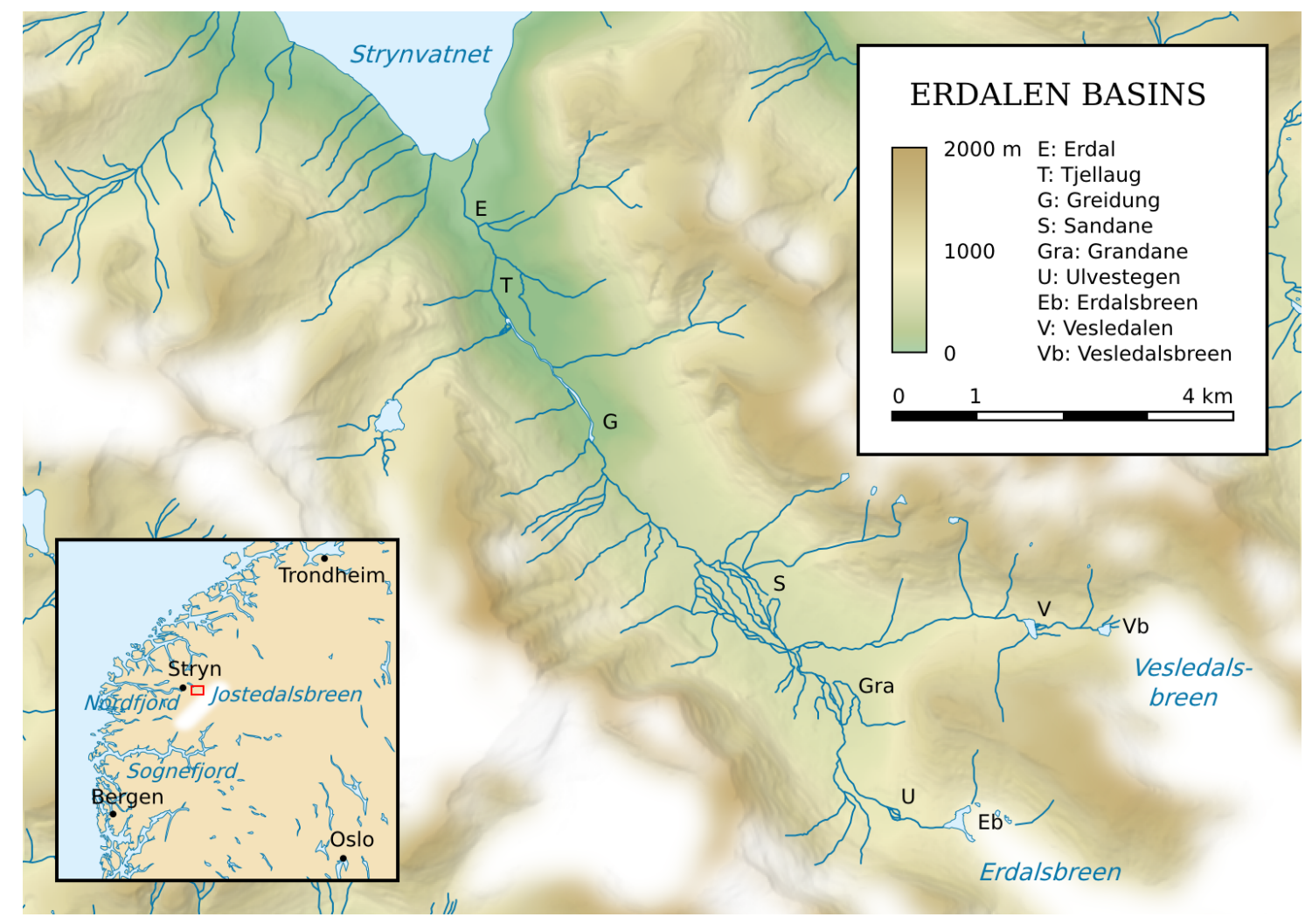

Figure 7: Shaded relief map of Erdalen showing the location of the overdeepened basins. Higher basins can be visualised by their drainage systems (S, Gra, U) or the glacial lakes which fill them (Eb, V, Vb.) Contains data from NorgeDigitalt (2008)

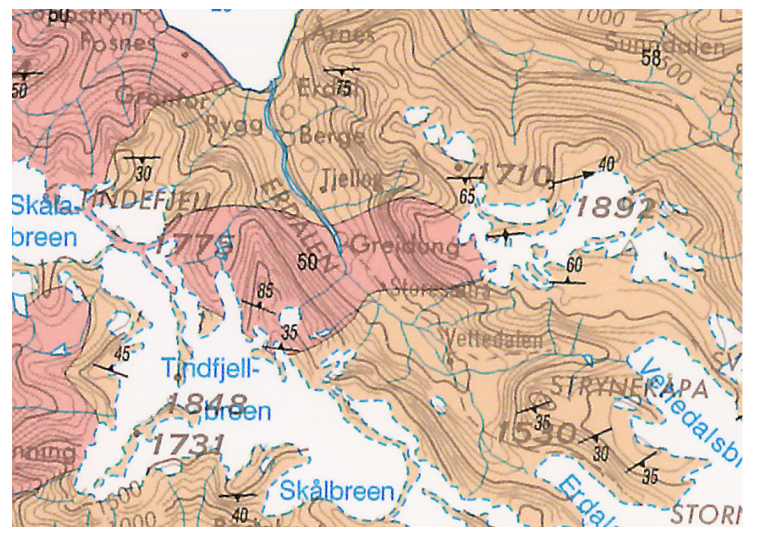

Figure 8: Extract from the bedrock map from Lutro and Tveten (1996) over the Erdalen area. Light orange is the granitic orthogneiss and pink the intrusive Quartzmonzonite. According to the mapping geologist Ole Lutro, the contact between the two rocks has been extrapolated from the sides of the valley and can therefore not be considered as exact on the scale of Erdalen basins. 


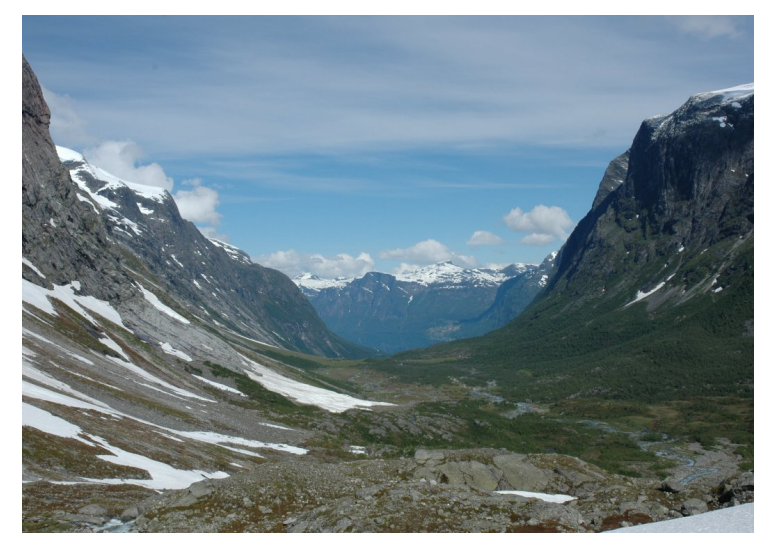

Figure 9: Higher Erdalen seen from Ulvestegen step. Grandane and Sandane basins are visible in the foreground, while the Hesthammeren rock threshold is hiding the rest. Notice the beautiful U-shaped profile of the valley, however disturbed by the sediments infillings. June 2008 .

(Larsen et al., 2006) and have reached all the way out onto the Norwegian shelf to the West. This implies that the Erdalen and Nordfjord area has been covered by different volumes of ice during numerous Quaternary glaciations and that maximum ice thickness in the area might have reached close to $2 \mathrm{~km}$ (Winguth et al., 2005).

\subsection{Morphology}

As many glacial valleys, Erdalen show a typical U-shaped cross-profile, which is approximately $3000 \mathrm{~m}$ wide and $1500 \mathrm{~m}$ deep (fig. 9.) The valley is approximately $10 \mathrm{~km}$ long and has a main confluence near its upper end. Seven basins are visible in the main valley, and two in the Vesledalen tributary (fig. 7.) The three lower basins are relatively low elevated and are used for agriculture (fig. 10.) The two higher basins are glacial lakes exposed during the last years by the recent retreat of Erdalsbreen and Vesledalsbreen.

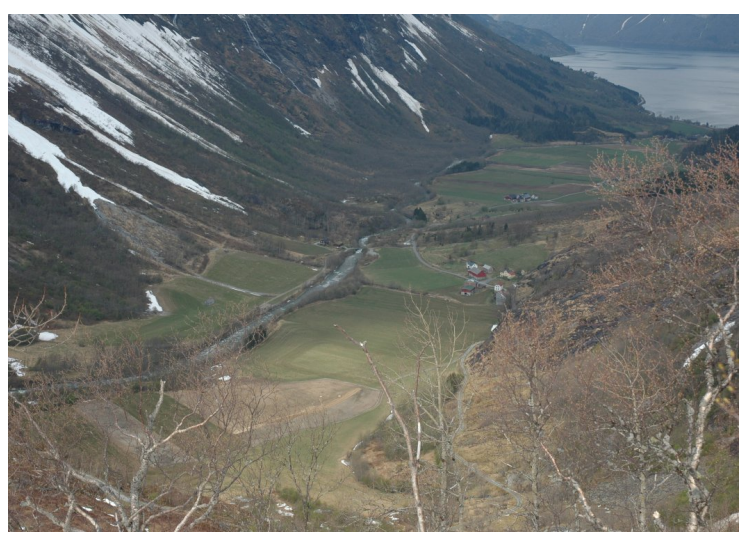

Figure 10: Lower Erdalen seen from the Hesthammeren hill. One can see, from left to right, Greidung and Tjellaug basins, and part of Erdal overdeepening and Strynvatnet in the distance. The slopes of the valley are covered by rockfall deposits and snow avalanches. April 2008.

Seismic investigation (Hansen et al., 2008) were made in Tjellaug, Greidung and Sandane overdeepenings, and their results are shown as a longitudinal profile of the bedrock elevation in fig. 11. The origin of Sandane, the deepest basin of the valley (fig. 9,) could be associated with the confluence between Vesledalen and Ercdalen. Tjellaug and Erdal basins are found below minor confluences as well, but the Greidung $78 \mathrm{~m}$ deep overdeepening is located in a homogeneous part of the valley. It can therefore not be explained by confluences and shows that the origin of the other basins must be sought elsewhere.

\section{Glacial plucking model}

The ice flow model we will use to calculate the glacier geometry is based on a shallow ice approximation (SIA.) Based on the data derived from the SIA model, subglacial cavities size can 


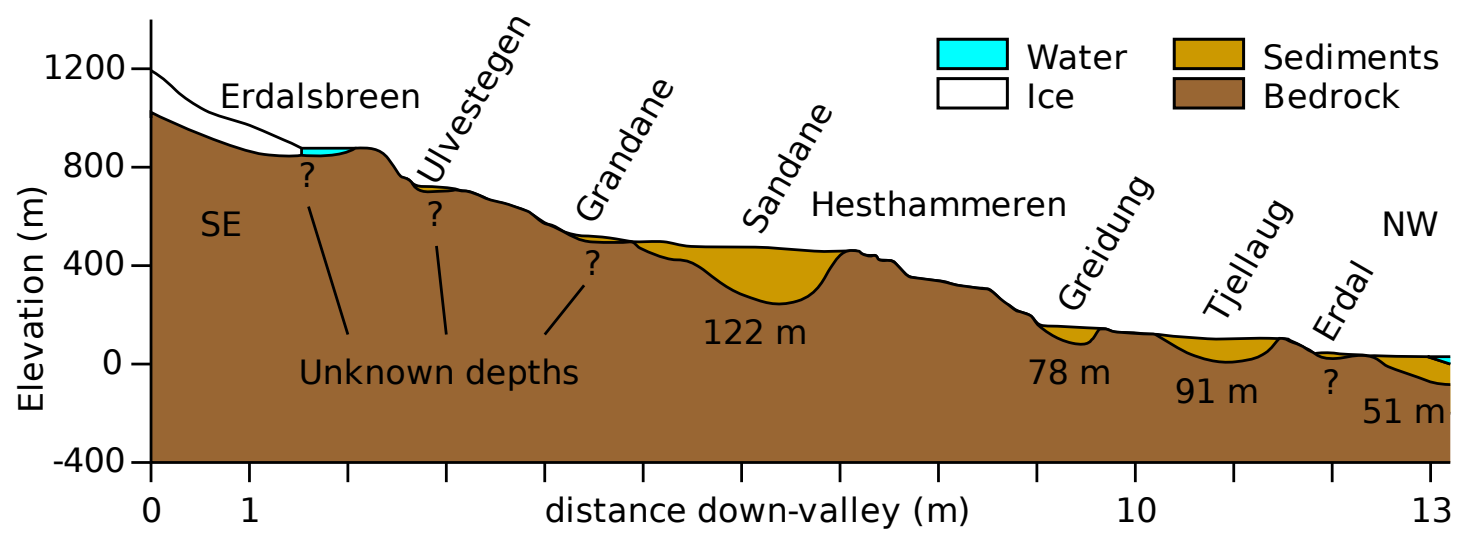

Figure 11: Longitudinal profile of Erdalen taken along the river bed showing surface elevation and sediment depths. Modified from an original drawing of Louise Hansen, see Hansen et al. (2008)

be calculated. Finally, based on cavity size, a plucking rate is computed using fracture mechanics. All quantities are defined in terms of distance down-valley $x$, and eventually elevation $z$ and time $t$. Time derivative of a function $f$ is written $\dot{f}$ and its space derivative is written $f^{\prime}=f_{x}^{\prime}$. A coordinate of a vector quantity $\vec{u}$ is mentioned by $u_{z}$, for instance. The model will be one-dimensional as we attempt to explain Erdalen features as longitudinal profile features.

\subsection{Ice flow model}

Let us consider a glacier flowing on its bed along the unique dimension $x$ (fig. 12.) As glaciers adapt to climatic conditions much faster than they erode the bedrock, we will for now assume that the bed morphology is unchanged. The simplest way to describe glacier morphology and velocity field is the SIA, which assumes the glacier is much larger in the horizontal space than thick. In the case of a channelized valley like the relatively narrow Erdalen, this approximation should be corrected by a scaling factor (Braun et al., 1999). However, as Erdalen has a

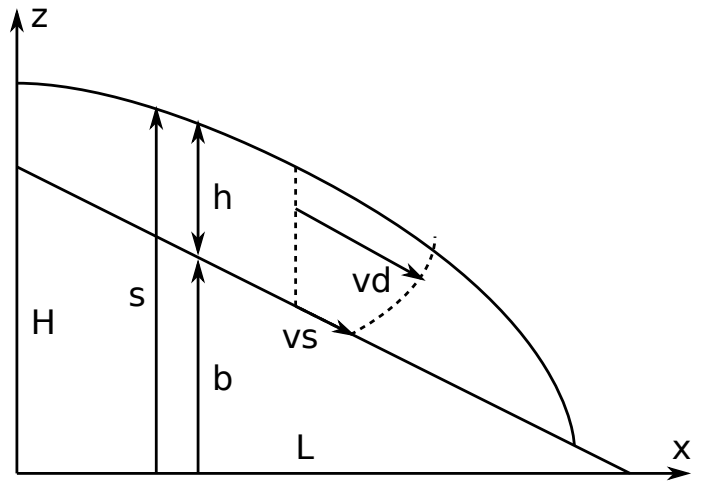

Figure 12: SIA model parameters.

roughly homogeneous width and height, we will use the SIA as it is.

\subsubsection{Continuity equation}

The ice can be modelled as an incompressible medium. The equation of mass conservation can therefore be written as:

$$
\begin{aligned}
0 & =\operatorname{div} \vec{v} \\
& =v_{x x}^{\prime}+v_{z z}^{\prime}
\end{aligned}
$$


Where $\vec{v}(x, z, t)$ is the ice velocity. By integrating over the glacier depth, and neglecting the variations of horizontal speed (SIA approximation:)

$$
\begin{aligned}
0 & =\int_{b}^{s}\left(v_{x x}^{\prime}(x, z, t)+v_{z z}^{\prime}(x, z, t)\right) \cdot d z \\
& =q_{x}^{\prime}(x, t)+v_{z}(x, s(x), t)-v_{z}(x, b(x), t)
\end{aligned}
$$

With $q_{x}^{\prime}(x, t)=\int_{b}^{s} v_{x x}^{\prime}(x, z) \cdot d z$ denoting the ice discharge per unit width. One could notice that the SIA identify tangent and horizontal velocity, as well as vertical and normal velocity. Consequently we can express conditions at the base $b$ of the glacier and the free surface $s$ in terms of vertical velocity:

$$
\left\{\begin{array}{l}
v_{z}(x, y, s(x, y), t)=\dot{h}(x, t)-a(x, t) \\
v_{z}(x, y, b(x, y), t)=0
\end{array}\right.
$$

Where $h$ is the glacier thickness and $a$ the local net mass balance, which is the difference between accumulated and melted snow depths. This leads us to the one-dimensional mass balance of the glacier:

$$
\dot{h}=a-q^{\prime}
$$

\subsubsection{Navier-Stokes equation}

The dynamics of the ice are described by the Navier-Stokes equation:

$$
\frac{d \rho \vec{v}}{d t}=d \overrightarrow{i v} \tau-g \overrightarrow{r a d} p+\rho \vec{g}
$$

$\rho$ is the volumetric mass of ice, $\vec{g}$ the acceleration of gravity, $p$ the pressure field and $\tau$ the deviatoric stress tensor. Because the internal friction forces in the ice are very high, we can neglect the inertial term:

$$
\left\{\begin{array}{l}
0=\tau_{x x x}^{\prime}+\tau_{x z z}^{\prime}-p_{x}^{\prime} \\
0=\tau_{x z x}^{\prime}+\tau_{z z_{z}}^{\prime}-p_{z}^{\prime}-\rho g
\end{array}\right.
$$

Again, since we are using the shallow ice approximation, horizontal derivatives can be neglected, as well as normal components of the deviatoric stress tensor.

$$
\left\{\begin{array}{l}
p_{x}^{\prime}=\tau_{x z z}^{\prime} \\
p_{z}^{\prime}=-\rho g
\end{array}\right.
$$

The last equation leads to hydrostatics equilibrium and can be reintroduced into the $p_{x}^{\prime}$ expression. The atmospheric pressure at the surface of the glacier is negligible.

$$
\left\{\begin{array}{l}
p=\rho g(s-z) \\
\tau_{x z}=\rho g(s-z) s^{\prime}
\end{array}\right.
$$

We are now able to express basal conditions in terms of the morphology of the glacier:

$$
\left\{\begin{array}{l}
p_{b}=\rho g h \\
\tau_{b}=\rho g h s^{\prime}
\end{array}\right.
$$

\subsubsection{Flow law}

The third input equation of a SIA model is the flow law. The ice is not a Newtonian fluid, rather its rheology is well described by Glen's power law (Hooke, 2005, p. 66).

$$
\dot{\epsilon}=A \cdot \tau^{* 2} \tau
$$

Where $\dot{\epsilon}=\frac{1}{2}\left(\operatorname{grad} \vec{v}+{ }^{t} \operatorname{grad} \vec{v}\right)$ is the strainrate tensor, $\tau^{* 2}=\frac{1}{2} \operatorname{tr}\left(\tau^{2}\right)$ the second invariant of the deviatoric stress and $A$ the Glen's law parameter, which depend on the temperature but will be taken as a constant is this model. In our case, the last equation becomes:

$$
\begin{aligned}
\frac{1}{2} v_{x z}^{\prime} & =A \cdot \tau_{x z}^{3} \\
v_{x z}^{\prime} & =2 A(\rho g)^{3}(s-z)^{3} s^{\prime 3}
\end{aligned}
$$


The integration also needs of the basal velocity $v_{b}$ which is still an unknown. A second integration leads to the expression of the ice discharge per unit width:

$$
\begin{gathered}
v_{x}=v_{b}+\frac{A}{2}(\rho g)^{3}\left(h^{4}-(s-z)^{4}\right) s^{\prime 3} \\
q=v_{b} h+\frac{2 A}{5}(\rho g)^{3} h^{5} s^{\prime 3}
\end{gathered}
$$

Using equation 1 leads to the equation of the glacier dynamics, which is equivalent with le Meur et al. (2004):

$$
\dot{h}=a-\left(v_{b} h\right)^{\prime}+\frac{2 A}{5}(\rho g)^{3}\left(h^{5} s^{\prime 3}\right)^{\prime}
$$

\subsubsection{Sliding speed}

The ice velocity can be divided in two components, which are the sliding speed $v_{b}$ and the deformation speed $v_{d}$ of the glacier (fig. 12.) If the deformation speed can be obtained - at a given sliding speed - from the last equation, the theories of glacier sliding are as numerous as the different ways to model a glacier bed. This is why the sliding motion of the glacier is often neglected in SIA modelling, which is indeed unfortunate since glacial erosion depends on basal velocity. However, we will demonstrate that this approximation can be justified in the case of an Erdalen-like glacier.

The sliding law problem has been discussed a lot in glaciology literature. Lliboutry (1987); Fowler (1987); Schweizer and Iken (1992), for instance, focused on the effect of water pressure on sliding over a sinuous linked-cavity bed profile This effect is known to cause big changes in glacier motion between the warm and cold season, and is responsible for glacier surge phenomena. However, the resulting sliding laws are not easy to be implemented in a SIA model and we will rather use the popular semi-empirical 'generalized Weertman law,' which fitted the data from Bindschadler (1983) well:

$$
v_{b}=k_{w} \frac{\tau_{b}^{3}}{p_{e}}
$$

Where $p_{e}=p_{b}-p_{w}$ is the effective pressure and $k_{w}$ a sliding constant. Using equation 2 , the basal velocity can then be expressed in terms of glacier morphology parameters.

$$
\begin{aligned}
v_{b} & =k_{w} \frac{\left(\rho g h s^{\prime}\right)^{3}}{\rho g h-p_{w}} \\
& =k_{w}(\rho g)^{2} \frac{h^{3} s^{\prime 3}}{\delta}
\end{aligned}
$$

The water pressure is usually described through a water level $h_{w}=p_{w} /(\rho g)$ (Hooke, 2005, p. 200) and here we will use a "dry depth" $\delta=h-h_{w}$. The new equation for the ice discharge becomes:

$$
q=(\rho g)^{2}\left(\frac{k_{w}}{\delta}+\frac{2 A}{5} \rho g h\right) h^{4} s^{\prime 3}
$$

\subsubsection{Non-dimensionalization}

In order to compare the two different terms of the last equation, and to easier implement it on a numerical model, we will non-dimensionalize it the following way:

$$
\begin{array}{rlrl}
h & =H \cdot h^{*} & & a=B \cdot a^{*} \\
s & =H \cdot s^{*} & q & =L B \cdot q^{*}
\end{array}
$$

Where $H, L$ and $B$ are respectively valley elevation, length and mass balance orders of magnitude. The new derivatives can be expressed using:

$$
\frac{\partial}{\partial x}=\frac{1}{L} \cdot \frac{\partial}{\partial x^{*}} \quad \frac{\partial}{\partial t}=\frac{B}{H} \cdot \frac{\partial}{\partial t^{*}}
$$




\begin{tabular}{ccc} 
& value & source \\
\hline$\rho$ & $916 \mathrm{~kg} \mathrm{~m}^{-3}$ & Hooke (2005, p. xiv) \\
$g$ & $9.81 \mathrm{~m} \mathrm{~s}^{-2}$ & \\
$A$ & $2.910^{-25} \mathrm{~Pa}^{-3} \mathrm{~s}^{-1}$ & Paterson (1994, p. 97) \\
$k_{w}$ & $84 \mathrm{~m} \mathrm{bar}^{-2} \mathrm{yr}^{-1}$ & Bindschadler (1983)
\end{tabular}

Table 1: SIA model parameters values. The Glen's law parameter $A$ is taken for a $-15^{\circ} \mathrm{C}$ ice, which seems to be a realistic mean value between glacial maximums and deglaciation stages.

The non-dimensional rewriting of the equations 1 and 4 leads to the following:

$$
\begin{gathered}
q^{*}=\frac{(\rho g)^{2}}{B} \frac{H^{7}}{L^{4}}\left(\frac{k_{w}}{\delta}+\frac{2 A}{5} \rho g H \cdot h^{*}\right) h^{* 4} s^{* / 3} \\
\dot{h}^{*}=a-q^{* \prime}
\end{gathered}
$$

The behaviour of the glacier can be describe by two non-dimensional numbers:

$$
\begin{aligned}
& \mathcal{S}= \frac{k_{w}}{B}(\rho g)^{2} \frac{H^{7}}{\delta L^{4}} \sim \frac{\text { sliding }}{\text { massbalance }} \\
& \mathcal{D}= \frac{5 A}{2 B}(\rho g)^{3} \frac{H^{8}}{L^{4}} \sim \frac{\text { deformation }}{\text { massbalance }} \\
& q^{*}=(\mathcal{S}+\mathcal{D} \cdot h) h^{* 3} s^{* / 3}
\end{aligned}
$$

We can note that the ratio between sliding and deformation does neither depend on $B$ nor $L$. If we choose $B=1 \mathrm{~m} / \mathrm{an}, H=1 \mathrm{~km}$ and $L=$ $10 \mathrm{~km}$ as realistic values for an intermediate-size Erdalen glacier, $\delta=200 \mathrm{~m}$ following the order of magnitude of data from Bindschadler (1983) on Variegated glacier in Alaska, and the values given in table 1 for others parameters, we find:

$$
\mathcal{S}=75 \quad \mathcal{D}=330
$$

This implies that the shape of the glacier is four times more affected by the ice deformation than its sliding. Even if sliding and deformation are of the same order of magnitude, we neglect the effect of sliding on ice topography by choosing a null value for the $\mathcal{S}$ coefficient. Equation 4 is then reduced to the following one. Note also that this effect would be emphasized for a warmer glacier, while the approximation would not be true in the case of a colder glacier.

$$
q^{*}=\mathcal{D} \cdot h^{* 5} s^{* / 3}
$$

\subsection{Bed separation calculation}

In order to calculate the plucking rate under the glacier, we need to know the effective normal stress $p_{i}$ applied by the ice on the bedrock. In a linked-cavity configuration of the bed, as mentioned above, this requires to estimate the extent of the water cavities, which is usually expressed by a bed separation coefficient $\sigma$, taken as the ratio between area of the cavity and total bed surface. Several glaciologists solved the problem of bed separation over a sinuous bed (Lliboutry, 1987; Fowler, 1987; Schweizer and Iken, 1992). We will however use an idealised stepped bed profile (fig. 13) similar to the one from Hallet (1996), which appears to be a more realistic approximation of plucking landforms in line with field observations made in Erdalen (fig. 3.)

Kamb (1987) solved the problem of cavity formation over a bedrock step using a linearly viscous ice approximation, and his solution seems to match closely with numerical modelling results from Iverson (1991). Neglecting basal melting, the length $c \cdot \cos \beta$ of the cavity is given by:

$$
c \cdot \cos \beta=4 \sqrt{\frac{\eta v_{b} \cdot l \sin \beta}{\pi p_{e}}}
$$

The basal velocity $v_{b}$ can be expressed in terms of the SIA parameters using once more the 


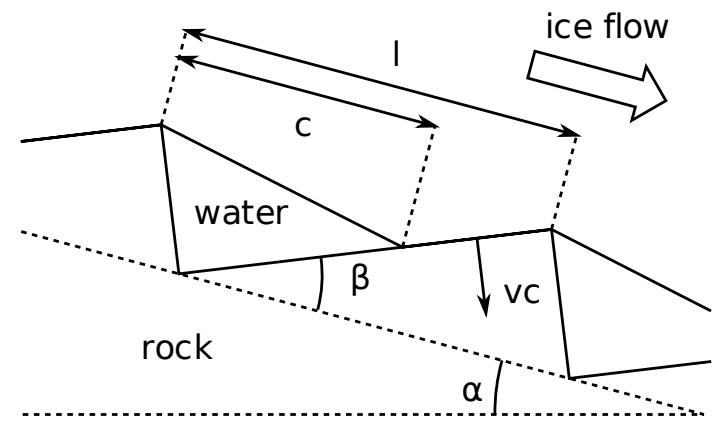

Figure 13: Bed model parameters.

Weertman's sliding law. The viscosity $\eta$ does not appear in our model as we used the Glen's flow law. However, we can assume a linearly viscous approximation to be reasonable for the lowest layer of the glacier, and express the viscosity parameter at the base in analogy with the Glen's law using $\eta=1 /\left(2 A \tau_{b}^{2}\right)$. This leads to:

$$
\begin{aligned}
c \cdot \cos \beta & =4 \sqrt{\frac{k_{w} \tau_{b}^{3} \cdot l \sin \beta}{2 A \tau_{b}^{2} \cdot \pi p_{e}^{2}}} \\
& =2 \sqrt{\frac{2 k_{w} \cdot l \sin \beta}{\pi A \rho g \delta^{2}} h s^{\prime}}
\end{aligned}
$$

The bed separation coefficient is then given by:

$$
\begin{gathered}
\sigma=\frac{c}{l}=2 \sqrt{\frac{2 \mu k_{w}}{\pi A \rho g \delta^{2}} h s^{\prime}} \\
\sigma=2 \sqrt{\frac{2 \mu k_{w}}{\pi A \rho g \delta^{2}} \frac{H^{2}}{L} h^{*} s^{* \prime}}
\end{gathered}
$$

Where $\mu=\sin \beta / l \cos ^{2} \beta$ is a parameter depending on the morphology of the bed. This morphology will then be an input to the model. Using $\mu=0.05$ and the values given above, the bed separation coefficient becomes:

$$
\sigma=5.7 \cdot \sqrt{h^{*} s^{* \prime}}
$$

\subsection{Fracture growth and erosion rate}

The dynamics of fracture propagation are generally described in terms of intensity factor $K$ under the theory of elasticity. If this intensity factor excess a critical value $K_{c}$, the fracture becomes unstable and start to propagate at a velocity approaching those of the $\mathrm{P}$-waves in the same medium. However, plucking is thought to be a slow process rather that an instant detaching of rock boulders by elastic crack propagation. Hallet (1996) assumed in his model that the quarrying rate was limited by the crack growth velocity. This assumption is strongly reinforced by field evidence, as it is usual to observe intermediatesize cracks on the lee side of plucking steps (fig.3.) In addition, Cohen et al. (2006) observed the growing of such a crack by acoustic emission (micro-seismic) events in a plucking experiment.

It is well known in rock mechanics that slow crack growth, also called sub-critical or quasistatic crack growth, can occur under very low values of $K$ (Martin, 1972). Atkinson (1982) suggested that the most important process involved in sub-critical crack opening under mode I (tensile cracks) for systems containing quartz is stress corrosion. In this process, the growing rate of the cracks is limited by chemical reactions weakening the tip of the crack. Moreover, stress corrosion can occur in preexisting joints, and was several times observed in association with acoustic emission events (Atkinson, 1982). In geologic materials, the experimental data on crack velocity $v_{c}$ is commonly fitted by Charles' power law, which was already used by Hildes (2001) to 
model plucking:

$$
v_{c}=v_{c 0} \cdot e^{\frac{-\Delta H}{R T}} K^{n}
$$

Where $\Delta H$ is an activation enthalpy, $R$ the gas constant, $T$ the absolute temperature and $n$ a stress corrosion index (Atkinson, 1982). As temperature variations under a glacier are insignificant from a geophysical point of view, we will neglect its effect on crack velocity. The values of stress corrosion index gathered by Atkinson (1982) for experiments on Westerley granite under water pressure are about $n=34$, which is the value I will use in my model. This already suggest an extremely high dependency of erosion rate on basal stress, rather than basal velocity. As the intensity factor is directly proportional to the applied differential stress, we can write:

$$
v_{c} \propto\left(p_{i}-p_{w}\right)^{n}
$$

We can notice that the glacier do not only apply a normal stress $p_{i}$ on the bed, but also a shear stress. Based on this consideration, the crack should preferentially open in the direction of larger differential stress. However, we consider here an idealized bed constituted by two perpendicular families of parallel and equidistant preexisting joints. As we will see later, this hypothesis is based on field observation. In addition, we can notice from SIA model results that $\tau_{b}$ is one order of magnitude lower than $p_{b}$, which allows us to neglect it in a direction which approach the vertical. Then, we consider that the plucking process is limited by the propagation rate of the nearly vertical cracks. Actually, the nearly horizontal joints are probably weakened by exfoliation processes resulting from repeated advances and retreats of the glacier. The quarrying rate of the bedrock is therefore directly proportional to the crack growth velocity $v_{c}$. In addition, a force balance over the bed in the vertical direction gives:

$$
\begin{gathered}
p_{b}=p_{w} \sigma+p_{i}(1-\sigma) \\
p_{i}=\frac{p_{b}}{1-\sigma}-p_{w} \frac{\sigma}{1-\sigma} \\
p_{i}-p_{w}=\frac{p_{b}-p_{w}}{1-\sigma}=\rho g \frac{\delta}{1-\sigma}
\end{gathered}
$$

The erosion rate can therefore be expressed as:

$$
\frac{d b}{d t}=\left(\frac{k_{e}}{1-\sigma}\right)^{n}
$$

Where $k_{e}$ is an erosional parameter which will be adjusted to fit the order of magnitude of measured erosion rates.

\subsection{Numerical implementation}

The computation is run using the parameters given above. In a first stage, starting from a given valley floor, the evolution of glacier thickness will be computed using equations 1 and 4 until the glacier reaches a steady state (accumulation is balanced by ablation.) In a second stage, the program will perform several steps, each of them comprising bed separation calculation using equation 6 , erosion of the valley floor with 7 and evolution of glacier thickness to a new steady-state profile. The time length of these steps are arbitrary.

Below $1000 \mathrm{~m}$ above sea level, the mass balance is taken as a linear function of elevation centered on the ELA at $600 \mathrm{~m}$, with a gradient of $1 \mathrm{~mm}$ a year per meter elevation. Above $1000 \mathrm{~m}$ above sea level, the mass balance is fixed to a constant maximum of $400 \mathrm{~mm}$ a year. 


\section{Results}

\subsection{Observed erosional features}

\subsubsection{Plucking and abrasion}

Plucking steps are visible all the way up on bedrock outcrops of the valley, from the forest covered slopes of the the lower basins to the bare rock slabs in the upper part. In most of the places, plucking seems to be the predominant process, forming steps which can be more than ten meters high, while abrasion plays only a secondary role, smoothing the landforms.

However, some localities exhibit a dominance of abrasion landforms. They are more often visible in the middle of the valley on the lee side of the rock thresholds, with the exception of the southern exposed part of Grandane basin. An intermediate case of largely smoothed steps is located at the lower end of Sandane basin.

\subsubsection{Exploitation of the bedrock}

Plucking steps sometime show a curved concave profile (fig. 14), in accordance with experiment by Cohen et al. (2006). This suggests a selfinduced crack opening, following the direction of maximum compressive stress. If several such features are observed in Hesthammeren, this is however a very seldom case at the valley-scale and plucking predominantly exploits the bedrock weaknesses, such as foliation in the upper part of the valley (fig. 3), or more often fractures networks, which are very dense in Erdalen old gneiss. More generally, it seems that the glacier takes advantage of the weak planes that fit the best with a defined morphology. One or more often two nearly vertical fracture planes, not necessary perpendicular to the glacier flow direction, build the steep face of the plucking steps, while

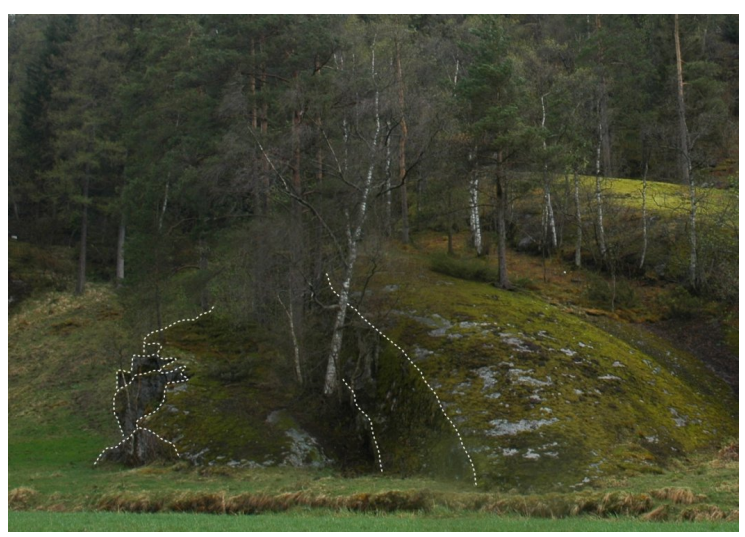

Figure 14: Plucking steps at the border of Tjellaug basin. The left step shows an irregular break in preexisting cracks, whereas the fracture in the middle is concave and smooth. April 2008.

an horizontal or gently up-valley dipping weak plane form the lee side.

\subsection{Bedrock geology}

Investigations were conducted in Erdalen during ten days in april and june in order to get an overview of the local bedrock geology. The accessible bedrock outcrops are not numerous, as they are often covered by sediments, rock avalanches deposits and abundant vegetation. On the valley sides, snow avalanche hazard limited field visit and observation.

The bedrock of Erdalen is mainly constituted by a granitic orthogneiss showing different degrees of partial melting. The three mainly observed textures are a homogeneous foliated gneiss, a layered gneiss which can contain migmatitic zones and amphibolite blocks, and finally a highly folded gneiss, whose foliation is apparently chaotic. Locally, a homogeneous granitic texture can be observed. The second rock type found in Erdalen is a large-grained 


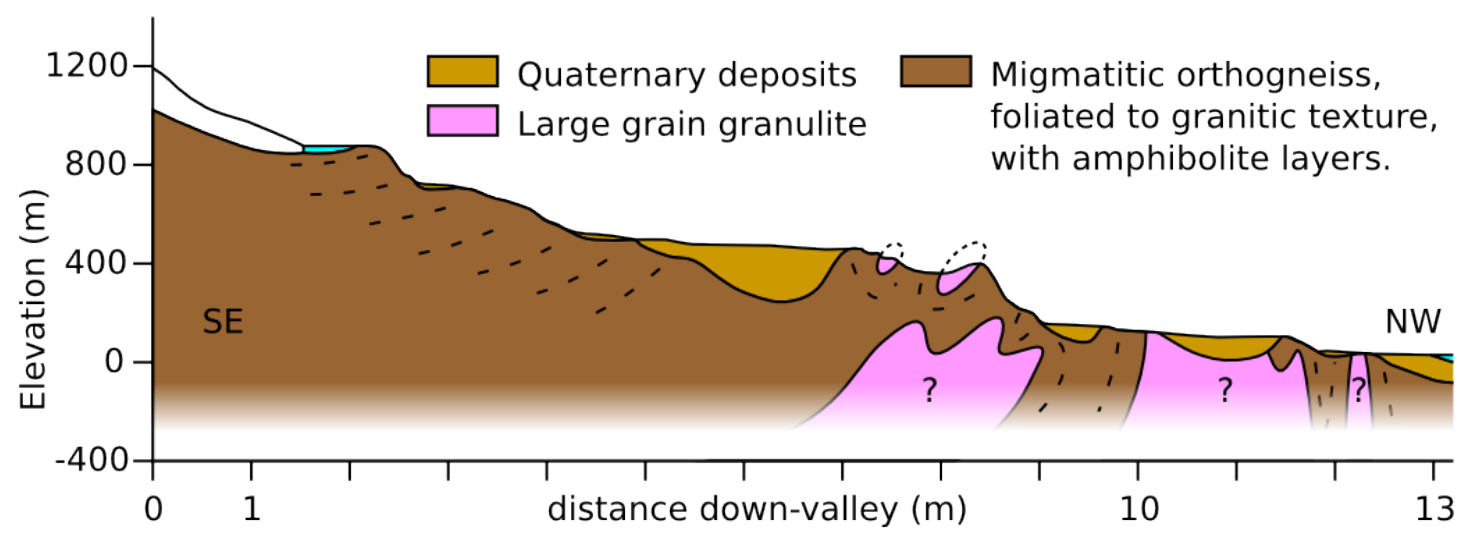

Figure 15: Interpreted bedrock geology profile in Erdalen crossing the Hesthammeren hill in its center part. Most of the observations were made on the right bank of the river. What appears as ellipses on Hesthammeren can also be interpreted as sheath folds crossing the profile plane in an oblique direction. Modified from an original drawing of Louise Hansen, see Hansen et al. (2008).

granitic rock, whose feldspars can reach several centimeters in size. Within the gneiss, it is hard to differentiate between the three textures previously described. However, the degrees of migmatization and folding both seem to increase at the neighborhood of the granulite. The contact between the two rocks have been observed only twice, in the very lower part of the valley in Erdal village, and on the way up to Hesthammeren, the small hill separating lower and higher Erdalen, where a small piece of granitic rock is found in the foliated gneiss. It shows that the granulite is intruding the gneiss. However, the transition between the two rocks is generally progressive, which in turn suggest intense deformation occured after the intrusion.

About the structure, the foliation of the gneiss looks quite regular in the upper part of the valley, but more variable in the lower part (fig. 15.) Contrary, the direction of lineation, when measurable, is slightly variable in the upper part, but keep a very homogeneous 80 degrees azimuth and east dip in the lower part. In addition, a stereographical projection of the measured foliation planes show that most of them contain this axis. This suggest a structure of sheath folds, or elongated boudins, along this direction of lineation. Local mapping in Hesthammeren furthermore suggest that the granitic rock build the center of these sheath folds or boudins.

Observations in lithology and foliation are gathered in a longitudinal profile (fig. 15,) which is nevertheless highly interpreted. Except for the granitic zones on the top of Hesthammeren, there is no apparently correlation between bedrock geology and location of the overdeepenings.

\subsection{Modelling results}

\subsubsection{Unviable bed separation}

The model described above exhibited problems mainly concerning bed separation with a mean value of three, which makes no sense since this 
implies that calculated cavity size stretches three bed steps in lenght. A dimension analysis shows that this effect is mainly due to a excessively high sliding velocity of the glacier (around $600 \mathrm{~m} / \mathrm{yr}$,) all other quantities implied in equation 6 having a reasonable order of magnitude. This leads us to try another experiment in which the sliding constant $k_{w}$ will be diminished by two orders of magnitude.

\subsubsection{Pre-existing overdeepening}

By choosing $k_{w}=10^{-10}$, equation 6 is reduced to:

$$
\sigma=0.62 \cdot \sqrt{h^{*} s^{* \prime}}
$$

The model is applied to an initial exponential bed which as been manually overprinted by an overdeepening-shaped anomaly in the form of a fourth-degree polynom. The resulting glacier and bed separation are shown in fig. 16. Despite the variations of elevation and slope of the glacier surface, the bed separation is a relatively homogeneous function. However, it is higher on the high slopes of the upper part of the profile, whereas the glacier sticks stronger to its bed at the places it is thicker, and especially in the middle of the overdeepening. The peak in bed separation at the lower end of the glacier should not be taken as implying high water pressure. At this place - and partially because of high bed separation - the water conduits in the glaciers are particularly large and reach atmospheric pressure. As cavitation and plucking can not occur there, the erosion will be inhibited in this part.

Five erosional steps have been applied and the resulting valley profiles are shown in fig. 17 . The erosion rate is maximum in the higher part of the valley, which leads to the formation of a steep headwall. Under realistic conditions, the

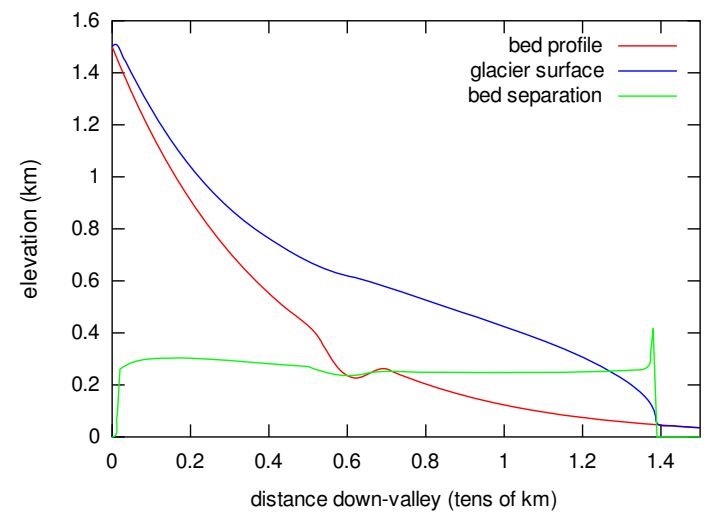

Figure 16: Modelled glacier morphology and bed separation over an exponential profile overprinted by an overdeepened anomaly. Note the minimum bed separation in the overdeepening. The equilibrium line is located at $0.6 \mathrm{~km}$ elevation

ice would not sticks anymore on this wall and an arête will be exposed. This is however not the case in our model, and therefore the erosion has been also inhibited under the very thin ice depths to simulate this effect.

The second result of this experiment is a slow flattening of the initial overdeepening because of a lower erosion rate in its center part. This suggest that glacial quarrying, as modelled in this study, could not be responsible for the formation of glacial overdeepenings.

\section{Discussion}

\subsection{The too high sliding velocity}

First, we can wonder why the results obtained with initial values are so extreme. As explained above, the problem can be summarize in a too high basal velocity of the glacier, or a too high value for the sliding constant $k_{w}$. This constant 


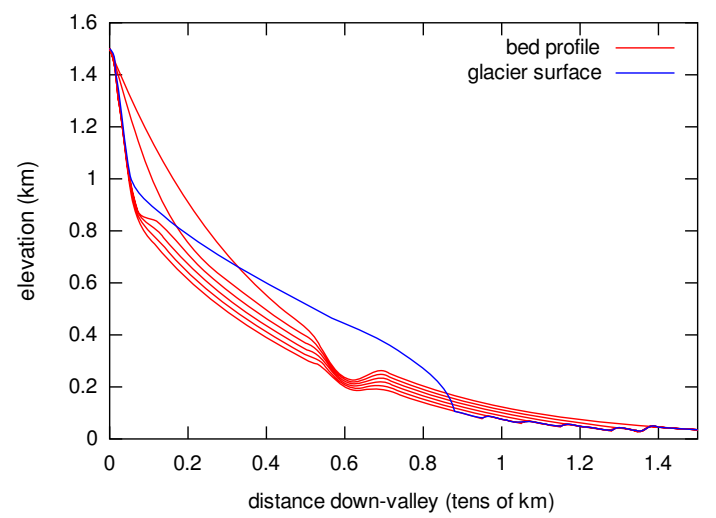

Figure 17: Modelled valley floor evolution by glacial erosion of an exponential profile overprinted by an overdeepened anomaly. Note the rapid carving at high altitudes and smoothing of the overdeepening. The ice thickness profile is drawn after the last erosional stage.

was determined by Bindschadler (1983) for Variegated glacier in Alaska, using relatively high water pressure. In addition, this glacier is subject to surges, short events in which the ice discharge can be increased by more than hundredfold. The main hypothesis in glaciology literature for such events is that after water pressure excess a critical value, the glacier would float on a basal water layer and reach dramatic sliding speeds. We can imagine that for a regular glacier, the water pressure will therefor be reduced, and the calculated $k_{w}$ constant smaller. Note that the "generalized Weertman's sliding law" is not supposed to explain the surge phenomenon. Note also that using the new sliding constant, the approximation of neglecting sliding in the SIA model becomes totally justified.

\subsection{Geomorphologic effects}

The model we used lead to an erosion rule in which denudation rate is proportional to basal stress at power twelve (equation 7.) This differ significantly from ice discharge or basal speed linear relationships, and have other effects on the glacier bed.

The previous experiment simulate well headwall erosion and arête formation. Note that such an headwall do not exist in Erdalen, as the ice is flowing from the Jostedalsbreen ice cap. The limit condition of null ice thickness at the highest point was however the simplest we could put in the SIA model. In addition, steep and high steps, such as the ones located in the highest part of Erdalen and Vesledalen, causing icefalls, could be somehow compared with an headwall situation, and therefore might have been formed according the proccesses described by the model. The results tend to support the idea that glacial plucking is the main cause for this headwall retreat, as already underlined by the modelling experiments of MacGregor et al. (2008). The origin of this strong localised erosion is correlated with the thin ice depth and steep glacier, which in turn creates bed separation, as demonstrated by fig 16.

The second main conclusion of the model is the flattening of overdeepenings. This totally contradicts with theories of positive erosional feedbacks (Hooke, 1991), as the model displays a negative feedback which can also be described qualitatively in the following terms. The higher water pressure in overdeepenings tend to increase bed separation at those places. However, this effect is counterbalanced by the slope effect, which lifts the glacier by increasing the basal stress. This in turn induce a lower erosion inside compared to outside the overdeepening. Conse- 
quently, Erdalen overdeepened basins can not be explained by strictly glacial processes.

\subsection{Erdalen basins}

This study allows us to make several hypotheses on the formation of Erdalen overdeepenings. As those can not be explained by glacial positive feedbacks, we have to rely on external factors enhancing their carving, such as valley width variations, confluences, preexisting fluvial morphology and bedrock resistance variation. Because Erdalen has been carved by the glacier of more than $1.5 \mathrm{~km}$, and has a relatively homogeneous width, the effects of the initial fluvial network and valley walls can be ignored.

The upper basins (Grandane and arounds) forms a quite typical confluence association in which the valley has been overdeepened both below and above a confluence point. This kind of morphology can be frequently observed and is strongly correlated with velocity fields observed over confluences (Gudmundsson, 1997). This suggest that those basins have to be related with the local accelerating and decelerating effects of a confluence between two comparable widths.

In the middle part of the valley, Hesthammeren exhibit a locally atypical bedrock pattern, containing some regions of not much fractured, large-grained granulite. This is also the place in which most self-induced cracking (fig. 14) were found, and the highest rock threshold in the valley. These observations tend to reinforce the lithological hypothesis for this, and consequently, for the Greidung basin located at its foot.

Finally, the two lower basins are not correlated with bedrock variations. Therefore they have to be explained by the confluences of small tributaries from the valley side.

\section{Conclusions}

Glacial erosion processes in general and the formation of glacial overdeepenings in particular are still enigmatic problems despite of significant theoretical advances during the past decades. A new model of glacial erosion, fields observations and bibliography works enabled to reach the following conclusions. Small-scale glacial overdeepenings are very probably the geomorphologic expression of external factor enhancing glacial erosion. These factors can be as various as valley widening, narrowing, tributary junctions, bedrock lithology and fracture density variations, and two neighbouring overdeepened basins could have different origins. In addition, glacial plucking was suggested to have an important role in glacial headwall erosion.

However, the plucking model presented can be improved by a better modelling of glacier hydraulics, snow and ice adhesion on steep slopes and climatic variations. Furthermore, a better quantification of the "generalized Weertman's sliding law" or any other sliding law through water pressure measurements on various glaciers is needed.

\section{Acknowledgments}

Thanks to Alexandre Schubnel, Aline Saintot, Christophe Pascal, Eiliv Larsen, Giulio Viola, Jochen Knies, Lena Rubensdotter, Louise Hansen, Marc-Henri Derron, Martina Böhme, Ola Fredin, Ole Lutro and Valentin Burki for interesting discussions and helps in writing the present thesys. Drawings were made using Inkscape, Gfortran, GNUplot, Grass GIS, ArcGIS and Gthumb. Compilated with LaTeX. 


\section{References}

Anderson, R. S., Molnar, P., and Kessler, M. A. (2006). Features of glacial valley profiles simply explained. Journal of Geophysical Research, 111:F01004. doi:10.1029/2005JF000344.

Atkinson, B. K. (1982). Subcritical crack propagation in rocks: theory, experimental results and applications. Journal of Structural Geology, 4(1):41-56.

Augustinus, P. C. (1995). Glacial valley crossprofile development: the influence of in situ rock stress and rock mass strength, with examples from the Southern Alps, New Zealand. Geomorphology, 14:87-97.

Ballantyne, C. K. (2002). Paraglacial geomorphology. Quaternary Science Reviews, 21:1935-2017.

Beaudevin, C. (2008). Les paysages glaciaires. http://www.paysagesglaciaires.net.

Benn, D. I. and Evans, D. J. A. (1998). Glaciers and Glaciation. Hodder Arnold publisher.

Bindschadler, R. (1983). The importance of pressurized subglacial water in separation and sliding at the glacier bed. Journal of Glaciology, 29(101):3-19.

Blikra, L. H., Longva, O., Braathen, A., Anda, E., Dehls, J. F., and Stalsberg, K. (2006). Rock slope failures in Norwegian fjord areas: examples, spatial distribution and temporal pattern. In Massive Rock Slope Failure: New Models for Hazard Assessment, NATO Science Series, IV: Earth and Environmental Sciences 49, pages 475-496.
Braun, J., Zwartz, D., and Tomkin, J. H. (1999). A new surface-processes model combining glacial and fluvial erosion. Annals of Glaciology, 28:282-290.

Burki, V., Hansen, L., Fredin, O., Andersen, T. J., Beylich, A. A., Jaboyedoff, M., Larsen, E., and Tønnesen, J.-F. (2008). Little ice age advance and retreat sediment budgets for an outlet glacier in western Norway. In review.

Cohen, D., Hooyer, T. S., Iverson, N. R., Thomason, J. F., and Jackson, M. (2006). Role of transient water pressure in quarrying: A subglacial experiment using acoustic emissions. Journal of Geophysical Research, 111:F03006. doi:10.1029/2005JF000439.

Fowler, A. C. (1987). Sliding with cavity formation. Journal of Glaciology, 33(115):255-267.

Fredin, O. (2002). Glacial inception and quaternary mountain glaciations in fennoscandia. Quaternary International, 95-96:99-112.

Gordon, J. E. (1981). Ice-scoured topography and its relationships to bedrock structure and ice mouvement in parts of Northern Scotland and West Greenland. Geografiska Annaler, 63A(1):55-65.

Gudmundsson, G. H. (1997). Measurements of ice deformation at the confluence area of Unteraargletscher, Bernese Alps, Switzerland. Journal of Glaciology, 43(145):1997.

Hallet, B. (1996). Glacial quarrying: a simple theoritical model. Annals of Glaciology, 22:18.

Hallet, B. (2008). Glacial erosion: processes, rates and landforms.

http://courses.washington.edu/ess431/ 
Lectures/lecture_2006/

Lect_11_Glacial_erosion_Proc1_2005.pdf.

Hansen, L., Beylich, A., Burki, V., Eilertsen, R., Fredin, O., Larsen, E., Lyså, A., Nesje, A., and Tønnesen, J. (2008). Stratigraphic architecture and infill history of Erdalen valley, Western Norway. In review.

Harbor, J. M. (1995). Development of glacialvalley cross sections under conditions of spatially resistance to erosion. Geomorphology, 14:99-107.

Harbor, J. M., Hallet, B., and Raymond, C. F. (1988). A numerical model of landform development by glacial erosion. Nature, 333:347349 .

Herman, F. and Braun, J. (2008). Evolution of the glacial landscape of the Southern Alps of New Zealand: Insights from a glacial erosion model. Journal of Geophysical Research, 113:F02009. doi:10.1029/2007JF000807.

Hildes, D. H. D. (2001). Modelling subglacial erosion and englacial sediment transport of the North American ice sheets. PhD thesis, The University of British Columbia.

Hooke, R. L. (1991). Positive feedbacks associated with erosion of glacial cirques and overdeepenings. Geological Society of America Bulletin, 103:1104-1108.

Hooke, R. L. (2005). Principles of Glacier Mechanics. Cambridge University Press, second edition.

Iverson, N. R. (1991). Potential effects of subglacial water-pressure fluctuations on quarrying. Journal of Glaciology, 37(125):27-36.
Kamb, B. (1987). Glacier surge mechanism based on linked cavity configuration of the basal water conduit system. Journal of Geophysical Research, 92(B9):9083-9100.

Kessler, M. A., Anderson, R. S., and Briner, J. P. (2008). Fjord insertion into continental margins driven by topographic steering of ice. Nature Geoscience, 1(5):365-369. doi:10.1038/ngeo201.

King, C. A. M. (1959). Geomorphology in Austerdalen, Norway. The Geographical Journal, 125(3):357-369.

Kooi, H. and Beaumont, C. (1994). Escarpment evolution on high-elevation rifted margins: Insights derived from a surface processes model that combines diffusion, advection, and reaction. Journal of Geophysical Research, 99(B6):12191-12209.

Larsen, E., Kjær, K. H., Deminov, I. N., Funder, S., Grøsfjeld, K., Houmark-Nielsen, M., Jensen, M., Linge, H., and Lyså, A. (2006). Late pleistocene glacial and lake history of northwestern Russia. Boreas, 35:394-424.

le Meur, E., Gagliardini, O., Zwinger, T., and Ruokolainen, J. (2004). Glacier flow modelling: a comparison of the shallow ice approximation and the full-Stokes solution. Comptes rendus de physique, 5:709-722.

Lliboutry, L. (1987). Realistic, yet simple bottom boundary conditions for glaciers and ice sheets. Journal of Geophysical Research, 92(B9):9101-9109.

Lutro, O. and Tveten, E. (1996). Geologisk kart over Norge, berggrunnskart Årdal m 1:250.000. 
MacGregor, K. R., Anderson, R. S., Anderson, S. P., and Waddington, E. D. (2000). Numerical simulations of glacial-valley logitudinal profile evolution. Geology, 28(11):10311034 .

MacGregor, K. R., Anderson, R. S., and Waddington, E. D. (2008). Numerical modeling of glacial erosion and headwall processes in alpine valleys. Geomorphology. doi:10.1016/j.geomorph.2008.04.022.

Martin, R. J. (1972). Time-dependant crack growth in quartz and its application to the creep of rocks. Journal of Geophysical Research, 77(8):1406-1419.

Matthes, F. E. (1930). Geologic history of the Yosemite valley. U.S. Geological Survey Professional Paper, 160.

NASA (2008). Visible Earth: Lambert glacier velocity map. http://visibleearth.nasa.gov/ view_rec.php?id=1618.

NorgeDigitalt (2008). Kartdata. http://www.norgedigitalt.no.

Oerlemans, J. (1984). Numerical experiments on large-scale glacial erosion. Zeitschrift für Gletscherkunde und Glazialgeologie, 20:107126.

Paterson, W. S. B. (1994). The Physics of Glaciers. Pergamon, third edition.

Schweizer, J. and Iken, A. (1992). The role of bed separation and friction in sliding over an undeformable bed. Journal of Glaciology, 38(128):77-92.

Sugden, D. E. and John, B. S. (1976). Glaciers and Landscape. Edward Arnold Publishers.
Terzaghi, K. (1962). Stability of steep slopes on hard unweathered rock. Géotechnique, 12:251270 .

Tomkin, J. H. (2003). Erosional feedbacks and the oscillation of ice masses. Journal of Geophysical Research, 108(B10):2488.

Tomkin, J. H. (2008). The geomorphologic consequences of incorporating glacial erosion in surface process models. Geomorphology. doi:10.1016/j.geomorph.2008.04.021.

Tomkin, J. H. and Braun, J. (2002). The influence of alpine glaciation on the relief of tectonically active mountain belts. American Journal of Science, 302:169-190.

Veyret, P. (1955). Le lit glaciaire : contradiction apparente des formes et logique réelle des processus d'érosion. Revue de Géographie Alpine, 43(3):495-509.

Wangensteen, B., Tønsberg, O. M., Kääb, A., Eiken, T., and Hagen, J. O. (2006). Surface elevation change and high resolution surface velocities for advancing outlets of Jostedalsbreen. Geografiska Annaler, 88A(1):55-74.

Winguth, C., Mickelson, D. M., Larsen, E., Darter, J. R., Moeller, C. A., and Stalsberg, K. (2005). Thickness evolution of the Scandinavian ice sheet during the Late Weichselian in Nordfjord, Western Norway: evidence from ice-flow modelling. Boreas, 34:176-195. 


\section{Appendix 1: model code}

Here follows the Fortran95 program used to produce fig. 16 and 17 . It will write six files containing respectively bed elevation, glacier thickness, glacier surface elevation, ice discharge, bed separation and erosion rate.

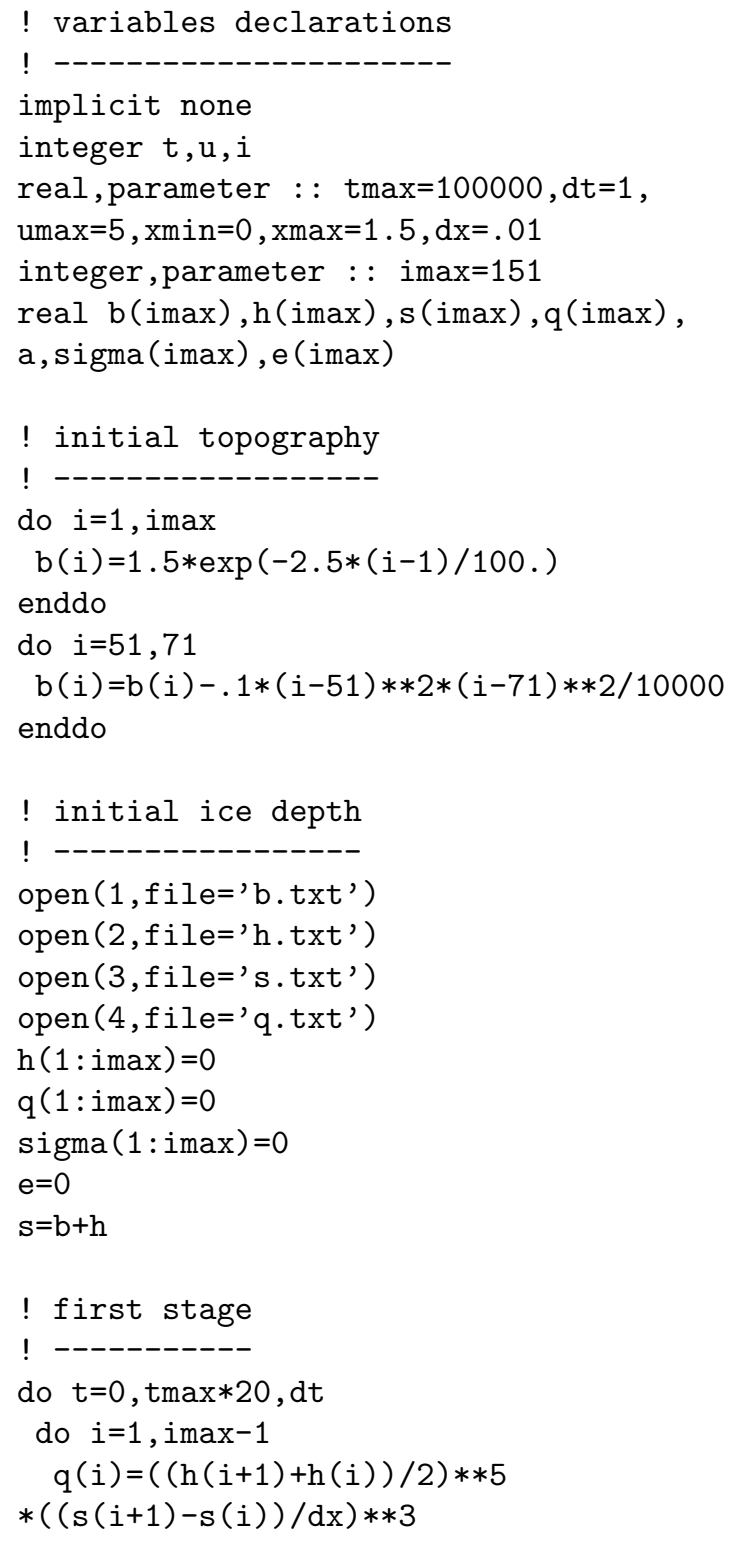

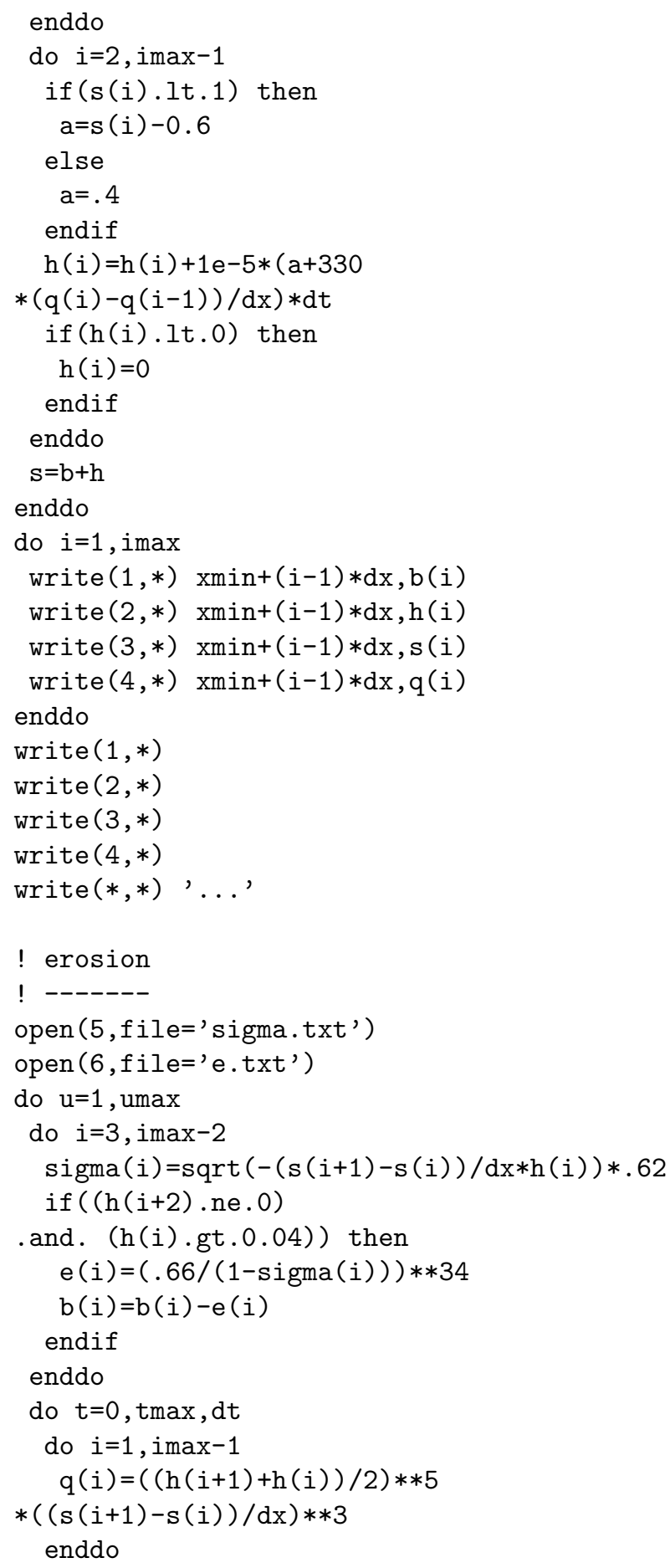




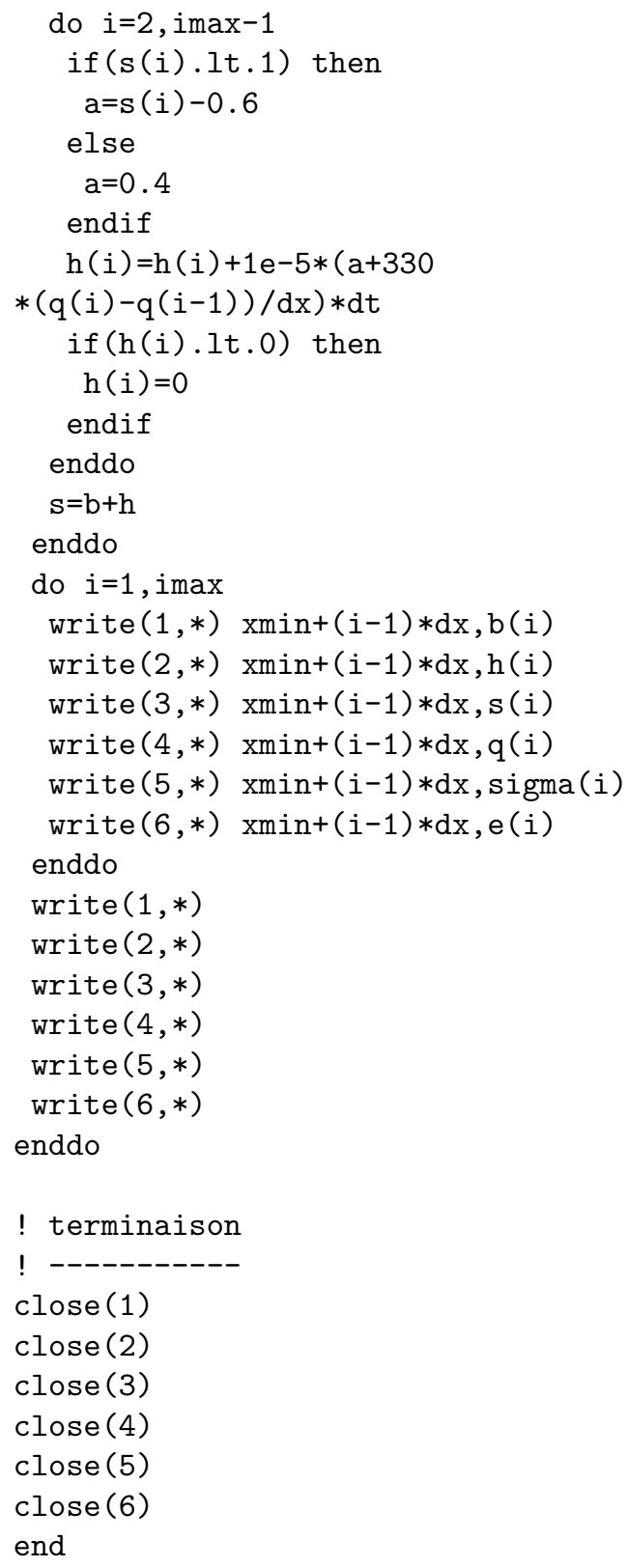

